\title{
SILVER FREE COINAGE AND THE LEGAL
}

\section{TENDER DECISIONS.}

Now that the national political contest, involving more particularly the proposition for the free and unlimited coinage of silver dollars at the ratio to gold of sixteen to one, has been decisively settled against the proposition, and in favor of maintaining the present gold standard of the currency, it seems to be an opportune time to call the attention of the thinking people of this country to the difficulties we would have encountered, in securing from the Supreme Court of the United States a pronouncement of the unconstitutionality of a silver free-coinage act of Congress, which would have been passed and made law, if the Democratic party had been successful at the polls.

Throughout the heated political contest, the opposition papers teemed with arguments to prove that the free coinage of silver at the stated ratio meant repudiation pro tanto of all existing obligations; and this argument, brought home to the small investor, the savings bank depositor, the holder of life insurance policies, and the wage-earner, unquestionably secured the defeat of the silver party. And, although during the canvass very little was said in speech or print of the protection against such a dishonest act of government which might be confidently expected as a last resort from the courts, in declaring a silver free-coinage law unconstitutional, this feeling was undoubtedly widespread, if not often expressed. This expectation, in the light of our history, was a most natural one. For the whole constitutional law of this country, both national and state, is impregnated with the policy of protection to vested interests. Our revolutionary forefathers seemed to have been fearful of an unfettered popular will, and their boast-and the states[198] 
men and jurists of the world have commended our government on account of it-was that they had established such a system of checks of one branch of the government upon another, as that it was impossible for any radical change to be effected in the form or policy of our government, which was not supported by the overwhelming second thought of the nation. As history has revealed it to us, the chief and most valuable check, devised by the framers of the national constitution, was the power of the courts to pronounce an act of Congress or state legislature unconstitutional, which contravened any provision of the written constitution.

Before the constitution of the United States was adopted and the present Union established, and while the Constitutional Convention was sitting at Philadelphia, the Congress of the Confederation was framing an ordinance for the government of the northwest territory; and, in setting forth the fundamental principles of justice, which should pervade and control the governmental acts of the territory, the ordinance provided inter alia:

"And in the just preservation of rights and property it is under. stood and declared that no law ought ever to be made, or have force in the territory, that shall in any manner whatever interfere with or affect private contracts or engagements bona fide and without fraud previously made."

This declaration was called forth by the very general desire to repudiate the inheritance of public indebtedness from the expenditures in the prosecution of the revolutionary war. In order to more effectually stem this tide of sentiment in favor of repudiation of public obligations, the Constitutional Convention inserted in the constitution the well-known provision that, "no state shall pass any law impairing the obligation of contracts." The convention did not think it necessary to impose the same explicit restriction upon the powers of Congress, probably because the national government was not expected at that time to play 
a very large or important rôle in the internal affairs of the country. But in the fifth amendment to the constitution, adopted subsequently, it was provided that

"no person shall be deprived of life, liberty or property without due process of law."

It is therefore one of the fundamental propositions of American constitutional law, that neither the national nor the state legislatures have the power by enactment to take one man's property and give it to another, even upon payment of compensation, except in the enforcement of the payment of debts. In the exercise of the right of eminent domain, a private owner's land may be taken for devotion to public use, upon payment of compensation. But it is not possible for land so condemned to be devoted to the strictly private use of another.

Property is defined as "any thing or object of value which one may acquire and own," and one of the commonest divisions of property in the law books is into things in possession and things in action. Things in action, or, to employ the old Norman-French term, choses in action, include every claim against another for money, or money's equivalent, which can be successfully enforced in a judicial action. It is manifest, therefore, that the constitutions, both national and state, guarantee one in the secure possession of things in action, as well as of things in possession. When the National Bankrupt Law, which cut off the claims of creditors of an insolvent debtor, was claimed to be a violation of the right of property in things in action, it was justified on the ground that the constitution of the United States had expressly authorized the enactment of the law, thereby making it an express exception to the ordinary constitutional guaranty of protection to vested rights.*

It is probably not an exaggerated statement that threefourths of the private property of the world are things in action, contracts, bonds, notes, open accounts, covenants,

* See Ogden vs. Saunders, s2 Wheat. 260 . 
mortgages, etc., and the great majority of these things in action are contracts, which call for the payment of money. It is also probably true, that the overwhelming majority of these current monetary obligations were created in this country since 1873 , when Congress demonetized silver, and put the country distinctly on a gold basis. These current monetary obligations were, therefore, made on a gold basis; i. e., when the bond or note, called for the payment of one thousand dollars, both debtor and creditor are conclusively presumed to have had in contemplation the payment of something, which, under the denominations of dollars and cents, would have enabled them to buy in the markets of the world the value in goods of the amount of gold which was put by the United States Government into one thousand gold dollars. If these parties had anticipated that, when the debt fell due, the debtor could extinguish his debt of one thousand dollars in gold by the transfer of five or six hundred gold dollars' worth of silver-which would enable the creditor to buy in the markets of the world only a little more than half the quantity of goods that he could get with the one thousand gold dollars, which he had expected to realize from the contract-the terms of the contract would certainly not have been the same. Common sense, as well as the expressed judicial opinion of this country in analogous cases, with the exception of the legal tender decisions, would force us to the conclusion that an act of Congress, passed subsequently to the making of the contract, which required the creditor to take five hundred gold dollars' worth of silver, whether in bullion or coined into silver dollars at the ratio of sixteen to one, would have the effect of taking away from the creditor one-half of his property, by reducing its purchasing power by one-half; and, that, for that reason, such an act of Congress was in violation of the fifth amend. ment of the national constitution, which prohibits the taking of private property.

It might be urged that the silver dollar of the present [20I] 
weight and fineness is already, and has been since 1878 , legal tender in payment of all debts, public and private; and that the free coinage of silver dollars at the same ratio would not change the rights of parties to existing private contracts. To this contention the answer may be given that, inasmuch as silver is coined, under the act of 1878 , and subsequent acts, in limited quantities only, the silver dollar has the character and effect of subsidiary coin, particularly since the goverument has uniformly given to the holder of silver dollars and treasury notes gold dollars, whenever they were demanded. In other words, the United States Government's guaranty that the silver dollar shall be maintained on a parity with the gold dollar, substantially makes the silver dollar as much a subsidiary coin as the fractional currency, whose intrinsic value is below the nominal value. This guaranty of the government alone maintains this parity; but if the guaranty were to be made worthless, as it would by a provision for the free coinage of silver, the gold would disappear from circulation, as it did in 1834 , and the country would at once settle down to a silver basis, resulting in a practical repudiation of about fifty per centum of existing obligations, unless the United States Supreme Court intervened with the declaration that this is a taking of private property without due process of law, which is inhibited by the national constitution.

It is a common rule of private conduct, that where one, even for a laudable purpose, does an act, which is in violation of a fundamental principle of ethics and justice, the incidental injurious consequences far outweigh in effect the good, or supposed good, which is immediately attained. And this is strikingly true with the declarations by the Supreme Court of the United States that Congress had the power to declare the United States treasury notes to be legal tender in payment of public and private debts. Those, who are not familiar with the opinions, filed in these cases, will be surprised to learn that Justices Strong and Gray, in 
delivering the opinion for a majority of the Court, in 12 Wallace, 457, and I Io U. S., 449, have plainly asserted the power of Congress to debase the currency, and make the debased currency legal tender in payment of existing obligations. In the legal tender cases, * the Court say:

"The obligation of a contract to pay money is to pay that which the law shall recognize as money when payment is to be made. . . . No one ever doubted that a debt of $\$ 1000$, contracted before 1834 , could be paid by 100 eagles coined after that year, though they contained no more gold than 94 eagles such as were coined when the contract was made, and this not because of the intrinsic value of the coin, but because of its legal value. . . . Every contract for the payment of money simply, is necessarily subject to the constitutional power of the government over the currency, whatever that power may be, and the obligation of the parties is therefore assumed with reference to that power. . . . It is thus clear that the power of Congress may be exercised, though the effect of such exercise may be in one case to annul and in other cases to impair the obligation of contracts."

In the same case, Mr. Justice Bradley says: "The mere fact that the value of debts may be depreciated by legal tender laws is not conclusive against their validity." And in Juillard vs. Greenman, $\uparrow$ Mr. Justice Gray, in delivering the opinion of the Court, said:

"So, under the power to coin money and to regulate its value, Congress may (as it did with regard to gold by the act of June 28, 1834, and with regard to silver by the act of February 28,1878 , ch. 20) issue coins of the same denomination as those already current by law, but of less intrinsic value, or containing less weight of the precious metals, and thereby enable debtors to discharge their debts by the payment of coins of less value."

Notwithstanding these very plain assertions of the power of Congress to debase the currency, by the modern imitation of the mediæval practice of clipping coins, I will make the effort to prove that the opinions of Justices Strong, Bradley and Gray are not indicative of what would be the judgment

* 12 Wall. 457.

† Iro U. S. 444 . 
of the Supreme Court on the constitutionality of a free coinage silver act.

First. The opinion as to the power of Congress to debase the currency was only a dictum, and appears in cases which hold that the Congress could make United States treasury notes legal tender. While I believe that the court erred in reaching that conclusion, the making of a legal tender out of treasury notes was only an incidental debasement of the currency, inasmuch as the notes were payable in coin, and the discount in the current valuation of the notes, due to the stress of war and its subsequent effect on the credit of the government, was only temporary. I am also fully persuaded that the legal tender decisions would never have been delivered, had it not been that a very large and powerful class of people, who had made debts in reliance upon the legality of the legal tender acts of 1863 , would have been seriously injured, if not ruined, by a decision of the court, that the treasury notes were not legal tender. In the beginning of his opinion in 12 Wallace, 457, Mr. Justice Strong said:

"It is also clear that, if we hold the acts invalid as applicable to debts incurred or transactions which have taken place since their enactment [the legal tender acts of 1863], our decision must cause throughout the country great business derangements, widespread distress and the rankest injustice. The debts, which have been contracted since February 25,1862 , constitute by far the greatest portion of the existing indebtedness of the country. They have been contracted in view of Congress declaring treasury notes a legal tender, and in reliance upon that declaration. Men have bought and sold, borrowed and lent, and assumed every variety of obligations contemplating that payment might be made with such notes. Indeed, legal tender treasury notes have been the universal measure of value. If now, by our decision, it be established that these debts and obligations can be discharged only by gold coin; if, contrary to the expectation of all parties to these contracts, legal tender notes are rendered unavailable, the government has become the instrument of the grossest injustice; all debtors are loaded with an obligation it was neier contemplated they should assume; a large percentage is added to every debt, and such must become the demand for gold to satisfy

$$
\text { [204] }
$$


contracts, that ruinous sacrifices, general distress and bankruptcy may be expected."

Can there be much doubt that if Mr. Justice Strong and his colleagues, who sustained the constitutionality of the legal tender acts, were now called upon to declare an act of Congress to be constitutional, which will compel creditors to receive in payment of existing debts money having only one-half the purchasing power of the present gold standard, they would be just as profoundly impressed with "the rank injustice" of such an enactment? As the late Austin Abbott used to say, the business of the judge is to give a legal reason for the conclusions of common sense; and I may add that, while the legal reason is usually considered as controlling the judgment of the court, the judgment is really dictated by the conclusions of common sense. These conclusions of common sense, rather than the assigned legal reasons, must be considered in attempting to forecast the decision of the same court in analogous cases. In this connection $I$ make bold to say that the quotation just given from the opinion of Mr. Justice Strong is a better guide to the determination of the social forces which brought about the legal tender decisions than the legal reasons assigned by him and his colleagues; as well as a better index of what the judgment of the court would be on the constitutionality of a silver free coinage act.

In the legal tender cases, the debtor class was in danger of being subjected to "rank injustice" by declaring the legal tender acts unconstitutional; while under a silver free coinage the creditor class would be the sufferers of "rank injustice," if the bill was held to be constitutional.

Secondly. When the legal tender acts were first passed, the nation was in the throes of a gigantic civil war, and the permanency of the union hung in the balance. It was as a war measure that the legal tende1 acts were first adopted; and while, in Juillard vs. Greenman,* the necessity of claiming

-110 U. S. 421. 
the power to make treasury notes legal tender, as a war measure, was not present, and the court really sustained the legal tender act of 1878 , which continued the legal tender character of treasury notes and provided for their reissue, on the technical ground that, conceding to the government the power to make its treasury notes legal tender, it was a legislative and not a judicial question when it was necessary to exercise the power, underlying all these legal tender decisions is the profound though, in the judgment of many, the mistaken conviction that the exercise of that power in 1863 was of immediate service to the national government in overthrowing the Southern Confederacy; and that it would be unwise to deny to the government a power which, however dangerous it might be if employed unwisely, was held to be highly beneficent in times of great emergency. No such special plea could be urged in behalf of the free coinage of silver. The duration of the government is not to be promoted, but rather endangered, by such an enactment. The only end to be attained by such a measure, in addition to the heavy percentage of repudiation of all existing obligations, is the speculative gain from the establishment of a different standard of valuation for future contracts. Such an end would not justify the government's interference with the obligations of debtors on existing contracts.

Thirdly. The legal reason, which led Justices Strong and Gray to the statement that Congress could debase the currency without violating any provision of the United States constitution, was based upon what Mr. Justice Strong asserted to be an uncontroverted and uncontrovertible proposition of law that an ordinary contract to pay a certain number of dollars

"was not a duty to pay gold or silver, or the kind of money recognized by law at the time when the contract was made, nor was it a duty to pay money of equal intrinsic value in the market. The obligation of a contract to pay money is to pay that which the law shall recognize as money when payment is to be made." 
And in Juillard $v s$. Greenman,* Mr. Justice Gray said:

"A contract to pay a certain sum in money, without any stipulation as to the kind of money in which it shall be paid, may always be satisfied by payment of that sum in any currency which is lawful money at the place and time at which payment is to be made."

I think it can be demonstrated that this is not American law, so far as it is claimed to involve the power of the government to debase the currency, and to compel the existing creditor to take in payment of his existing claim a depreciated or debased currency at its face value. The foreign authorities, which are cited by these judges, need not be taken into consideration; because nowhere else in the world is a court authorized or enjoined to avoid a legislative act on any ground whatever. When, however, we read this proposition of the law of contracts, in the light of Faw $v s$. Marsteller, $\dagger$ cited by Mr. Justice Strong in support of his proposition, that the government can debase the currency without violating existing contracts, we are forced to the conclusion that its only meaning, as a proposition of American law, is that the creditor is obliged to take in payment of his claim, whatever is rightfully made legal tender at the time that the debt falls due. For example, it is a common proposition of commercial law that a negotiable promissory note may be made payable in this country, calling for the payment of a sum of money of a foreign denomination, but it is actually payable in the legal tender of this country, unless otherwise agreed upon; and the amount in the legal tender of this country, which is due on the note, is computed from the relative values of the units of the two systems of coinage. The commercial world holds, as the fundamental unit of value, to the purchasing power of the denomination. And while the government of the United States may vary the intrinsic value of its coins, and therewith change their ratio of value with foreign coins, it has not the constitutional power to increase or diminish the

* ito U. S. 42 I.

+2 Cranch. 29. 
purchasing power of the money called for in settlement of an existing contract. This seems to be the irresistible conclusion from the opinion of Chief Justice Marshall in Faw vs. Marsteller.*

During the revolutionary period of our existence as a nation, each of the states, as well as the Continental Congress, had issued paper money or treasury notes, in such large sums, that this money had become greatly depreciated in value, and a proportionate premium had to be paid for gold and silver. Although there was a general expectation that at some time in the future the depreciated paper would be retired, and specie payment be resumed, most contracts were made in the expectation that they would be performed by payment in this depreciated currency.

The Virginia Legislature, along with provision for resumption of specie payment, had established a scale of valuation of the depreciated paper money in specie at different periods of its circulation, and declared that contracts, which had been made during the circulation of the paper money, when paid in specie, should be reduced in amount to the real value which the paper money had in specie at the time when the contract was made. For example, a contract calling for the payment of $\$ 1000$, made when the paper money was worth in specie only fifty cents on the dollar, the creditor could only recover $\$ 500$ in specie.

In the case of Faw $v$ s. Marsteller, a deed of sale was made in 1779 of land upon a perpetual ground-rent of 26 pounds current money of Virginia. It was contended by the grantor's assigns that this contract did not come within the statute, because it was a continuing contract, and that the rentals falling due after the resumption of specie payment, should be construed as obligations arising after that date, and that these rentals should be paid in full in specie. Chief Justice Marshall denied this claim, holding that the contract did

- 2 Cranch. 29. 
come within the operation of the statute. The Chief Justice said, continuing:

"It seems to be the date and not the duration of the contract which was regarded by the Legislature. The act is applied directly to the date of contract, and the motive for making it was that contracts entered into during the circulation of paper money, ought in justice to be discharged by a sum different in intrinsic value from the nominal sum mentioned in the contract, and that when the Legislature removed the delusive standard, by which the value of the thing acquired had been measured, they ought to provide that justice should be done to the parties."

The Virginia Legislature had, however, provided in the act referred to, that where the scale of values proved in any particular case to work injustice, the courts were empowered to make a special inquiry into the value in specie of the claim in the particular contract, and that this judgment of the court should determine the amount to be paid in liquidation of the contract. Chief Justice Marshall held, from the evidence before him, that this was one of those extraordinary cases, which were not justly provided for by the scale of values, and ordered a special inquiry to determine the annual rental value in specie of the land at the time when the land was sold. Surely the great exponent of the sanctity of contracts would not have rendered this decision, had he believed in the power of the government to change the intrinsic value of the unit of money, and compel parties to existing contracts to receive in payment the debased coin at its face value. In the light of the facts of this case, and the specifc judgment of the court, the statement of Chief Justice Marshall in his opinion in the same case,* which is quoted by Mr. Justice Strong in the legal tender cases, that "according to the law of contracts all moneys accruing under it, which were not received during the currency of paper, would be payable in such other money as might be current at the time of payment,"

must be taken to mean only that the creditor cannot object

- 2 Cranch. 29.

[209] 
to the kind of money offered him in payment, because it was not money at the time when the contract was made.

The same principles controlled the United States Supreme Court in laying down the rule that where, during the prevalence of the civil war, a note or contract was made in the Southern States within the Confederate lines, calling for the payment of a number of dollars, and which remained unpaid at the re-establishment of peace, the sum payable in the lawful money of the United States on such a note must be ascertained by the determination of the value in such money of the Confederate currency at the time and place, when and where such note or contract was made.*

The fact that the same court rendered these decisions at the same time that they were deciding the legal tender cases, indisputably sustains my contention that the legal tender cases are not to be taken as a judicial determination, that the United States Government can impair the obligation of existing contracts by compelling, in performance of such contracts, the receipt of a debased currency at its face value.

Fourthly. The dicta of these justices are still further weakened by their claim that the Unired States Government had reduced the intrinsic value of its coin, and thus impaired the obligation of existing contracts in 1834 . The latter half of the proposition is not true.

Under the act of I 792, the silver dollar was established as a unit of value in the ratio to gold of $I 5$ to $I$; but by 1823 , it became very plain that the true ratio was 16 to $I$. As a result of this depreciation of silver, the gold passed out of circulation and was either sent to Europe or hoarded in this country. Inasmuch as both silver and gold were legal tender, and the debtor could pay his contracts in either coin, he would surely pay in the cheaper metal. At that time, therefore, this country was on a silver basis, and all

- See among other cases, the Confederate Note Cases, 19 Wall. 548; Stewart ws. Salomon, 94 U. S. 434 ; Cook us. Lillo, ro3 U. S. 793 ; Wilmington, etc., R. R. Co. w. King, 91 U. S. 3 . 
the existing contracts were made in reliance upon payment in silver. The creditor gained nothing therefore from this relative appreciation of the gold dollar. The only one who profited by it was the possessor of the gold doliar, and his profit depended solely upon the extra quantity of gold in the gold dollar. Inasmuch as the country was already on a silver basis, in re-establishing a parity between the two metals, Congress acted wisely in reducing the quantity of gold in the gold dollar, because it was the scarcer coin, and had already passed out of active circulation. Values were in nowise disturbed by this congressional enactment; they would have been if the intrinsic value of the silver dollar had been increased, for all contracts were then made on a silver basis. The situation is now completely changed. We are on a gold basis, and the terms of all contracts are determined by a reference to the gold standard. The remonetization of silver at a ratio which would make the silver dollar inferior in intrinsic value to the gold dollar would at once take us to the silver basis, and the values of all monetary obligations would be proportionately reduced.

This exposition seems to make clear that while the legal tender cases would, as prominent precedents, have proved stumbling-blocks in the way of securing a declaration that a silver free coinage bill was unconstitutional, so far as it applied to existing contracts; such a declaration might have been confidently expected, if the court had been called to pass upon the question. Happily, the verdict of the people at the polls makes an appeal to the court unnecessary.

New York Unitersity.

Christopher G. TiedhuaN. 